\title{
МІСІОНЕРСЬКА ТА КУЛЬТУРНО-ПРОСВІТНИЦЬКА ДІЯЛЬНІСТЬ ГАЛИЦЬКИХ МОНАХІВ-ВАСИЛІЯН НА ПІДКАРПАТСЬКІЙ РУСІ
}

Анотація: У статті проаналізовано напрями, зміст і трансформації під впливом суспільних викликів місіонерської та культурно-просвітницької діяльності галицьких монахів-василіян на Підкарпатській Русі.

Монахи-василіяни вбачали у своєму покликанні активну роботу з молоддю, засновували апостольські товариства, а також активно займалися видавничою діяльністю. Їх місії виходили далеко за межі однієї держави, а просвітницька діяльність давала позитивні зрушення у сфері освіченості молоді. Хоча така активна громадська позиція галицьких монахів не завжди подобалася владі Підкарпатської Русі, але вони мали підтримку місцевого єпископату.

Ключові слова: галищькі монахи-василіяни, Чин Святого Василя Великого, реформа, церква, Закарпатms

Чернечі ордени мають достатньо усталений ритм функціонування, який вибудовувався цілими поколіннями монахів. Проте, модерні віяння та нові суспільні виклики обумовлюють необхідність адаптації традиційних устоїв до суспільних вимог. Саме суспільні виклики вплинули трансформацію місіонерської та культурно-просвітницької діяльності монахів-василіян. Історична ретроспектива створює можливість для запозичення досвіду минулого та застосування його на сучасному етапі.

Проаналізувавши науковий доробок з окресленої нами теми, ми можемо виокремити працю представника чернецького ордену А. Пекара ${ }^{1}$. Автор виклав матеріал у контексті історичних подій в Україні. Чималу увагу він присвятив організаційному устрою чернечого Чину Святого Василія Великого (ЧСВВ) у різні історичні періоди. Заслуговує на увагу його робота «Нариси історії церкви Закарпаття» ${ }^{2}$, в якій детально проаналізовано зміни організаційного устрою та статусу християнської церкви в єпархіях Закарпатської України, з'ясовано ролі та функції у церковній структурі як духовенства так і мирян, висвітлено трансформацію обрядово-літургійних традицій. Також А. Пекар присвятив чимало своїх публікацій реформі ЧСВВ. Цінність для вивчення даної проблематики також становлять публікації В. Фенича ${ }^{3}$ та В. Кічери ${ }^{4}$.

\footnotetext{
* Maйороші Марія Андріївна - магістр історії, директор музею історії Ужгородського національного університету, ORCID: https://orcid.org/0000-0001-9734-9951; e-mail: majorossym@gmail.com

${ }^{1}$ Пекар А. «Записник» о. Гліба Г. Кінаха, ЧСВВ, про початки реформи на Закарпатті // Analecta Ordinis S. Basilii Magni. Sectio II. Vol. XII (XVIII). Fasc. 1-4. Sumptibus PP. Basilianorum. Romae, 1985. C. 117-164.

${ }^{2}$ Пекар А. Нариси історії Церкви Закарпаття. Т. III. Монаше життя. Ужгород: КП «Ужгородська міська друкарня», 2014. 220 c.

${ }^{3}$ Фенич В. Пряшівський єпископ Павло Гойдич та Мукачівська греко-католицька єпархія // Науковий вісник УжНУ, серія «Історія». 2011. Вип. 27. С. 169-176; Фенич В., Цапулич О. Малоберезнянський Свято-Миколаївський монастир та нарис історії Чину св. Василія Великого на Закарпатті. Ужгород: Вид-во В. Падяка, 2004. 188 с.

${ }^{4}$ Кічера В. «Заснування і діяльність монастирів Чину св. Василія Великого на Закарпатті (1733-1950 роки)»: автореф. дис.... канд. іст. наук: 07.00.01 / УжНУ. Ужгород, 2008. 20 с.
} 
Основою нашої роботи є грунтовна джерельна база. Найбільшу цінність для нашого дослідження у Державному архіві Закарпатської області (ДАЗО) становлять документи фондів «Мукачівський Чернечий монастир» (№64) та «Правління Мукачівської грекокатолицької єпархії» (№ 151). Документи, що містяться у фонді «Мукачівський Чернечий монастир ${ }^{5}$ нами було використано для висвітлення питання про реформу ЧСВВ. Потужною інформативністю характеризуються й опубліковані джерела, зокрема церковна преса 6 .

Метою нашої статті є аналіз змін, які відбулися у місіонерській і культурнопросвітницькій діяльності монахів-василіян внаслідок перемін суспільно-політичної ситуації на Галичині та Закарпатті.

Проводячи реформу, монахи-василіяни розгорнули свою діяльність на декілька напрямків. Після реформування монастирів першочерговим завданням стало підняття авторитету чернецтва та посилення позицій Греко-католицької церкви, оскільки чехословацька влада приховано підтримувала Православну Церкву. Саме тому василіяни розгорнули масштабний місіонерський рух. Засновником цього руху став Стефан Решетило (ЧСВВ), який у 1924 р. прибув на Підкарпатську Русь з Галичини ${ }^{7}$. Почасти всі монахи брали участь у місіях і реколекціях, але найбільш активними були С. Решетило, П. Гойдич, П. Булик, П. Котович, Т. Скиба. Крім того, у місії почали залучати і єпархіальних священиків. Для цього потрібно було створити структуру руху.

Головними осередками, навколо яких об’єднувалися священики-місіонери, стали місійні товариства. Одними $з$ перших таких товариств ще у 1924 р. С. Решетило та П. Гойдич заснували товариство «Оборони віри» (основним гаслом якого було збереження власних традицій) і «Товариство Пресвятого Серця Христового» (почитання Пресвятого Ісусового Серця, збирання щоп'ятниці для молитви за прощення всіх людських гріхів, проведення відпустів і суплікацій (благання Святих Тайн) ${ }^{8}$. За два роки «Товариство Пресвятого Серця Ісуса» налічувало понад 2700 членів різних національностей (русини, словаки, угорці), які завзято виконували покладені на них обов'язки'.

На цьому місіонери не зупинилися. 30 квітня 1925 р. той же Стефан Решетило проводить перше зібрання членів нового місійного «Товариства імені святого Йосафата», на якому було затверджено статут, вибрано управу та зачитано програму дій ${ }^{10}$. До головної управи ввійшли: Олександр Хіра - голова товариства, Еміліан Бокшай - секретар, Павло Гойдич (ЧСВВ) - касир. Були також окреслені основні завдання товариства: влаштування місій у кожному селі, місійні курси для світських священиків, поширення католицької преси, проведення духовних реколекцій три рази на рік ${ }^{11}$. Священики активно включалися у місійну працю монахів.

Завдяки таким старанням монахів-василіян центр головних відпустів перемістився з Маріяповчанського монастиря до Святомиколаївського монастиря в Мукачеві. У 1926 р.

\footnotetext{
${ }^{5}$ Державний архів Закарпатської області (ДАЗО). Ф. 64. Оп. 1-5.

${ }^{6}$ Душпастыръ. Урядовый органъ Епархіи Мукачівської и Пряшевской / отв. ред. о. Ал. Илницкый. Ужгород; «Уніо», 1927-1928.

${ }^{7}$ Душпастыръ. 1928. Ч. 12. С. 310.

${ }^{8}$ Кічера В. Освітньо-релігійна діяльність реформованих василіанських монахів...

9 Душпастыръ. 1927. Ч. 4. С. 207.

${ }^{10}$ Первое собрание членов миссійного товариства ім. св. Йосафата. // Душпастыръ. 1925. Ч. 5. С. 240.

${ }^{11}$ Ibid. C. 241.
} 
зусиллями монахів для Мукачівського монастиря римським папою Пієм ХІ була подарована стародавня дорогоцінна ікона Пресвятої Діви. Ця ікона, разом з листом від кардинала Гаспаррі, була відправлена 6 квітня з Риму, а вже 16 червня 1926 р. зайняла своє почесне місце у василіянській обителі ${ }^{12}$. Цей величний жест з боку папи римського, який і духовно, інколи навіть матеріально підтримував реформу монахів і місійний рух, неабияк підніс дух греко-католицького люду Підкарпатської Русі.

Про успіх місійної діяльності говорять наступні цифри: тільки за 1926 р. в Мукачівському Святомиколаївському монастирі було проведено 15 місій, відправили 1876 служб, проголосили 6 проповідей і причастилося 22992 вірники $^{13}$. Але 28 серпня 1928 р. успенський відпуст у монастирі на Чернечій горі став особливим як за масштабною кількістю визначних гостей, так і за кількістю вірян. Цього дня Мукачівський монастир приймав також високоповажного гостя - митрополита Галицького Андрея Шептицького. Участь у відпусті взяло близько 50 тисяч паломників, 10 тисяч яких сповідалися у 50-ти священиків ${ }^{14}$. Завдяки цій знаковій події слава про монастир на Чернечій горі розлетілася далеко за межі Підкарпатської Русі.

На увагу заслуговує також святкування в Ужгороді свята Христа Царя за участі тодішнього мукачівського єпископа Петра Гебея, коли участь у процесії взяло 15 тис. людей і все це масове дійство завершилося біля монастиря отців-василіян, які роздали вірним 3000 брошур $з$ проповідями та молитвами ${ }^{15}$.

Miсії проводилися не тільки у великих містах Підкарпатської Русі як-от Ужгород, Мукачево, Хуст, також проходили у таких селах як Тячів (за участі Стефана Решетила, Василя Лара, Теофана Скиби, присутні близько 3 тис. чол. ${ }^{16}$, Симерки (за участі Теофана Скиби) ${ }^{17}$, Білки (за участі єпископа Петра Гебея та Стефана Решетило й Олександра Ільницького) $)^{18}$, Новоселиця (за участі Теофана Скиби) ${ }^{19}$ та багатьох інших. Особливу увагу під час місій душпастирі приділяли молоді.

Слава про успішні місії монахів-василіян на Підкарпатті поширилася закордоном. Два отці-василіяни Теофан Скиба та Микола Легеза у листопаді 1928 р. на запрошення пітсбурзького екзарха єпископа Василя Такача вирушили з місіями до Сполучених Штатів Америки $^{20}$. Місії тривали півроку. Гроші, які монахи зібрали під час свого перебування, висилали керівництву Мукачівського монастиря для підтримки новіціяту. Наприклад, у результаті першої місії у Прінстоні отці вислали до Мукачівської єпархії 283 дол. ${ }^{21}$ Крім того, успішність їх діяльності проявилася також у тому, що четверо-п'ятеро чоловіків зго-

\footnotetext{
${ }^{12}$ Циркуляр епископа Мукачевской греко-кат. епархии о даровании монастырю Пием XI иконы «Святой Матери» // ДАЗО. Ф. 64. Оп. 3. Спр. 1328. Арк. 1-12; Душпастыръ. 1926. Ч. 7. С. 382-384.

${ }^{13}$ Благовьстникъ. 1927. Ч. 6. С. 95.

${ }^{14}$ Свобода (Ужгород). 1928. Ч. 35. С. 2-3.

${ }^{15}$ Душпастыръ. 1927. Ч. 10. С. 596-597.

${ }^{16}$ Благовъстникъ. 1927. Ч. 7. С. 126.

${ }^{17}$ Душпастыръ. 1928. Ч. 7-9. С. 233-234.

${ }^{18}$ Душпастыръ. 1928. Ч. 8-9. С. 198.

${ }^{19}$ Ibid. C. 236.

${ }^{20}$ Душпастыръ. 1928. Ч. 12. С. 310.

${ }^{21}$ Кічера В. Місійна діяльність реформованих монахів василіан на Закарпатті у 20-30-х рр. XX ст. // Науковий вісник Ужгородського національного університету. 2008. Вип. 20. С. 31.
} 
лосилося приїхати та вступити до Мукачівського новіціяту.

Одним з найбільших досягнень у цьому напрямку діяльності було створення у вересні 1925 р. Центральної канцелярії оборони віри (ЦКОВ).

Ця організація мала своїм покликанням підняти евентуально пограбовану Грекокатолицьку церкву, відбивати схизматичні напади мирним шляхом і розповсюджувати релігійну та просвітницьку літературу. Головою ЦКОВ став Олександр Ільницький, радниками - Василь Желтвай та Еміліян Бокшай, редакторами - Василь Шельковь і Олександр Хіра, а також єпископський секретар і радник - Олександр Стойка ${ }^{22}$.

Робота ЦКОВ не залишалася непоміченою. Наприклад, менше ніж за півроку, тобто станом на початок 1926 р., цим об'єднанням було роздано 3380 апологетичних брошурок, а кількість членів невпинно зростала кожного місяця ${ }^{23}$. Також через цю організацію отцівасиліяни ініціювали збори священиків, одні з таких відбулися 5 травня 1928 р. в Мукачівському монастирі ${ }^{24}$. Ці збори були важливими, адже вони зближували священиків 3 різними поглядами, ставили перед ними одну спільну мету - посилення позицій ГКЦ на Підкарпатській Русі та задоволення духовних потреб своїх вірних.

Цікаві спогади про місіонерську діяльність монахів-василіян знаходимо в інтервю М. Малинича (ЧСВВ):

«Згодом зачали ходити вістки і про те, що появилися монахи-місіонарі, які на своїх місіях навчають людей основних правил християнської віри. Завдяки цьому люди заспокоюються, перестають переходити у схизматицьке православ'я, а деякі з них і перейшли з нього знову у греко-католицтво. На одній із таких місій пощастило побувати і мені. Вона відбувалася у сусідньому селі Верхні Ворота, де знаходилася парохія, звідки отець-парох, тоді о. Василь Ларій, обслуговував і моє невелике тоді село, село Лази.

Тоді я взнав, що ті місіонарі-монахи - то отці-василіяни. Цю місію у Верхніх Воротах проводили С. Решетило, Т. Скиба і, можливо, ще хтось помагав їм, котрого я не бачив. Я був замалий тоді, щоб я вслідив зрозуміти то, що вони проповідували. Мені сподобалося те, що я бачив у них і що чув від них, їх свіжу живу рідну мову. Так мені сподобалося, що в мені збудилося бажання: коли б я був таким. Мої побожні батьки, душпастирський труд отця-пароха В. Ларія, любителя свого народу, і врешті оця місія названих отців-василіян і сталися для мене тим, завдяки чому я став монахомвасилиянином» ${ }^{25}$.

Як бачимо, сумлінна праця монахів-василіян не залишалася без винагороди. Чим далі - тим більше молоді проявляла цікавість до діяльності монахів, вступали на навчання до них, цим самим поповнюючи лави духовних отців для вірних, які потребували їх підтримки у важкі післявоєнні часи.

Крім місій отці-василіяни також активно проводили реколекції, які часто відвідувала молодь і місцева інтелігенція. Тільки за неповних чотири роки монахами було здійснено 49 місій і майже стільки ж реколекцій ${ }^{26}$.

\footnotetext{
22 Душпастыръ. 1925. Ч. 9. С. 465-466.

23 Душпастыръ. 1926. Ч. 7. С. 268.

${ }^{24}$ Душпастыръ. 1928. Ч. 5. С. 127.

${ }^{25}$ Інтерв’ ю з Мелетієм Малиничем. АІІЦ. Ф. П1. Оп. 1. Спр. 204.

${ }^{26}$ Душпастыръ. 1928. Ч. 12. С. 310.
} 
Під проводом вже згадуваних нами отців Ероніма Малицького, Стефана Решетило, Петра Котовича, Павла Гойдича, Теофана Скиби духовні вправи - реколекції регулярно відбувались щорічно у гімназіях, учительських семінаріях і при монастирях. Для прикладу, у 1926 р. в Мукачеві під час з'їзду місійного товариства одночасно відбулися реколекції для вчителів і жінок священиків ${ }^{27}$.

Отцем П. Гойдичем (ЧСВВ) було також започатковано рух Апостольства Молитви осередком якого став Ужгородський монастир. Влітку 1924 р. у дворі Ужгородського монастиря була освячена церква св. Василія Великого, яка і стала центром Апостольства молитви. Почитання Пресвятого Серця Ісусового швидко поширювалося мукачівською єпархією і кількість членів Апостольства молитви невпинно зростало ${ }^{28}$. Отже, місійний і реколекційний рухи, започатковані реформованими монахами-василіянами, набули швидкого поширення по всій території Мукачівської єпархії. Знедолені та духовно спустошені вірні знаходили у цих зустрічах духовну втіху.

Крім того, монахи-василіяни також активно займалися культурно-просвітницькою діяльністю. Для досконалішого виконання цієї роботи монахам була потрібна власна друкарня, адже найближча знаходилася в Жовкві. Саме тому стараннями Петра Котовича настоятеля Ужгородського монастиря, при обителі було відкрито друкарню, цим самим налагодивши власне видавництво. Основні кошти для друкарні (а їх було потрібно чимало) надали папа Пій ХІ та єпископ Крижевацької єпархії Діонісій Нарядій.

Спочатку в друкарні працювали цивільні особи, а згодом цю справу опанували і монахи. Зазвичай залучалося сім-вісім ченців. Звісно, більшість літератури, яка видавалася, була релігійного змісту. Наприклад, з 1927 р. місцева друкарня починає видавати «Календарь Благовьстника», а з 1930-го року монахи перебрали і редакцію єпархіального «Благовьстника». Нерідко друкувалися також проповіді місіонерів (у 1927 р. було видано проповідь С. Решетила «Милий місіонер») ${ }^{29}$ та різного роду брошурки для вірних, які роздавалися безкоштовно.

Загалом за десятирічну діяльність друкарня отців-василіян випустила таку кількість літератури: 181250 примірників щомісячної газети «Благовьсник», 150920 примірників релігійних газет, 76767 релігійних книжок, 78100 молитовників, 26800 церковних календарів, 20000 наукових творів і 173250 релігійних брошур. Ці цифри говорять про неабиякий успіх монахів-василіян у видавничій справі.

Не залишалися байдужими василіяни і до виховання молоді. На базі Ужгородського монастиря було продовжено та розширено базу для навчання дітей. У 1926/27 навчальних роках інтернат отців василіян утримував 85 учнів. Діти отримували освіту та лікарську допомогу, забезпечувалися харчуванням і необхідними речами для повсякденного вжитку (найбідніші отримували все це безкоштовно). У 1931/32 навчальному році освіту, морально-релігійне виховання та лікарську опіку здобували 60 учнів. Причому, як вже згадувалося вище, при інтернаті діяли хор і драматичний гурток . Директором на той час був Мирон Калинець (ЧСВВ), заступником - Йосиф Мартинець (ЧСВВ), префектами - Йоса-

\footnotetext{
${ }^{27}$ Душпастыръ. 1926. Ч. 7. С. 398.

${ }^{28}$ Онисько Франциск. Отець Еронім Йосиф Малицький (1865-1925). URL: https://www.osbm.org.ua/index.php/publikatsiyi/istoriya/634-1865-1925

${ }^{29}$ Душпастыръ. 1927. Ч. 5. С. 282.
} 
фат Рога та Антоній Станканинець (ЧСВВ) $)^{30}$.

30 червня 1937 р. розпорядженням міністерства шкільництва Чехословаччини від при монастирі було утворено класичну гімназію - на той час єдину на території Підкарпатської Русі ${ }^{31}$. Вихованці інтернату часто їздили з театральними виставами по населеним пунктам Підкарпатської Русі. Ось так саме з ініціативи отців-василіян відбувалося культурне піднесення краю, а також вони стали першочерговими помічниками Церкви в поширенні знань і святості життя.

Велику допомогу у просвітницькій і виховній діяльності надавали сестривасиліянки, які прибули до Ужгорода в 1924 р. Під патронатом єпископа Петра Гебея п’ять сестер (у тому числі й ігуменя Чину с. Магдалина Гуменюк, ЧСВВ, яка з 1922 р. очолювала інтернат сестер-василіянок у Пряшеві) прибули із Галичини для того, щоб перебрати опіку над сиротинцем св. Єлизавети в Ужгороді (на той час у сиротинці навчалося 72 дитини $)^{32}$.

Сестри-василіянки не гаяли часу і вже 12 листопада 1925 р. в Ужгороді було відкрито новіціят для сестер, який посвятив особисто єпископ Петро Гебей, наголосивши при цьому на важливості цього історичного моменту ${ }^{33}$. В новостворений новіціят на навчання одразу ж вступило п'ять дівчат. В основні функції сестер входили наступні справи: утримання сиротинці, догляд за хворими, навчання дітей катехізису, особливо дівчат від 15 до 25-ти років.

Сиротинці в основному існували завдяки пожертвам вірних ГКЦ. Одними з найбільших меценатів у цій справі були подружжя Августина та Ірини Волошин, які завжди ставали на захист сиротинців. Фінансову допомогу на відкриття новіціяту та підтримання благодійної діяльності сестер часто надавали вірні із-за кордону, а саме із США, за що мукачівський єпископ Петро висловлював їм щиру подяку ${ }^{34}$.

За період з 1924 по 1936 роки в Ужгороді та на його околицях всього було засновано три заклади для утримання бідних дітей ${ }^{35}$. Таким чином, сестри-василіянки вміло доповнювали своєю благодійною та культурно-просвітницькою діяльністю непосильну працю отців-василіян.

Незважаючи на всі позитивні моменти під час перебування галицьких ченців на Підкарпатській Русі зустрічалися і різного роду перешкоди. Від активної діяльності монахів-василіян не була в захваті чехословацька влада та москвофіли, які, як вже згадувалося, всіма силами підтримували поширення православ'я на Підкарпатській Русі. Більшість непорозумінь виникало саме на релігійному та національному грунті. Отці-василіяни вважалися поширювачами українства, а також закидали антидержавну діяльність.

Найбільші напади здійснювали на Стефана Решетила як на «небезпечного чужинця», який веде «протидержавну діяльність»", саме тому його декілька разів депортували з території Чехословацької держави.

\footnotetext{
${ }^{30}$ Інтернат ОО. Василіан в Ужгороді // ДАЗО. Ф. 64. Оп. 3. Спр. 1551. Арк. 70.

${ }^{31}$ Свобода. 1937. 5 серпня. С. 3.

32 Душпастыръ. 1924. Ч. 9. С. 474.

33 Душпастыръ. 1925. Ч. 10. С. 517.

${ }^{34}$ Душпастыръ. 1926. Ч. 1. С. 372-375.

${ }^{35}$ 35-ліття діяльності ігумені василіан // Свобода. 1936. 10 вересня. С. 2.

${ }^{36}$ Пекар А. Нариси історії Церкви Закарпаття. Т. ІІІ. Монаше життя... С. 128.
} 
Однією з таких гучних акцій проти отців-василіян стали виступи емігранта І. Вислоцького на сторінках «Підкарпатських гласов», де він критикував роботу ЦКОВ та отців П. Котовича, П. Булика, Г. Кінаха та С. Решетила ${ }^{37}$. у 1926 р. поліцією було здійснено обшуки в Мукачівському монастирі і знайдено брошуру про приналежність Підкарпатської Русі до українських земель ${ }^{38}$. Після цього монаха Стефана Решетила було вислано до Галичини. Він особисто звертався до мукачівського єпископа Петра Гебея з проханням, щоб владика клопотав про його повернення до Підкарпатської Русі ${ }^{39}$. Також ігумен Мукачівського монастиря Петро Булик надсилав до єпископа Петра листа, в якому просить про допомогу у вирішенні проблеми Стефана Решетила, підкреслюючи, що ніхто з монахів не мав і не має на думці «украинизовати народь», позаяк свідомі того, що політикою має займатися світська інтелігенція ${ }^{40}$.

Не залишалися осторонь прихильники монахів-василіян: 140 священиків і 6872 вірні Мукачівської єпархії та 23 священики і 1650 вірних Пряшівської єпархії зібрали підписи за повернення С. Решетила. У 1927 р. монах знову повернувся до Ужгородського монастиря ${ }^{41}$.

Все ж пристрасті не вщухали. Того ж 1927 р. з'являється нова публікація у «Руському вестнику», де мова йшла про те, «що волошинові хочуть зробити С. Решетило новим єпископським секретарем» і знову домагалися його виселення. На цей раз знову був організований ще більш масштабний процес на захист василіян - 8500 підписів ${ }^{42}$.

Як відомо, мукачівський владика Петро Гебей разом з крижевацьким єпископом Діонісієм Нарядієм і пряшівським єпископом Павлом Гойдичем (який сам належав до василіян) були найголовнішими покровителями й оборонцями ЧСВВ. Саме тому владика П. Гебей негайно дає письмову відповідь на прохання П. Булика, в якій висловлює своє невдоволення з приводу натисків на ЧСВВ й особисто на С. Решетила:

«Извистно Вамь, Высокопреподобный Отче, что такь я, як вси съ мною чувствующіи священники богоспасаемой епархіи мукачевской вполни уважаеме и оциняеме отъ початка неутомиму диятельность всихъ Отцевъ Чина Св. Василія Великаго, которы в ділі переведенія реформы въ нашей Подкарпатской русской каф. провинціи отъ Римскаго Апостолскаго Престола опредиленой, такъ корректно и похвально участвують» ${ }^{43}$.

Навіть це не допомогло і вже у 1928 р. Стефана Решетило було відкликано до Львова на уряд секретаря та прокуратора Галицької провінції, а з 1929 р. він став настоятелем поверненого василіянського монастиря у Варшаві ${ }^{44}$.

Після смерті мукачівського єпископа Петра василіяни остаточно втратили одного 3

\footnotetext{
${ }^{37}$ Душпастыръ. 1926. Ч. 7. С. 379-380.

38 Донесения игумена монастыря ордена св. Василия Великого в Ужгороде о выступлениях газеты «Русский вестник» против членов ордена // ДАЗО. Ф. 151. Оп. 13. Спр. 583. Арк. 1.

${ }^{39}$ Лист-звернення о. С. Решетило, ЧСВВ до єпископа Мукачівського П. Гебея від 02.02.1927 // ДАЗО. Ф. 151. Оп. 13. Спр. 582. Арк. 2.

40 Лист о. П. Булика до Мукачівського єпископа П. Гебея від 14.05.1927 // ДАЗО. Ф. 151. Оп. 13. Спр. 583. Арк. 2-3.

${ }^{41}$ Душпастыръ. 1927. Ч. 4. С. 229.

${ }^{42}$ Пресові напади проти отців Василіан. Душпастыръ. 1927. Ч. 6. С. 323.

${ }^{43}$ Високопреподобному о. Поликарпу Буликъ, заступнику протоигумена ЧСВВ, игумену въ Мукачівському від 20.05.1927 // ДАЗО. Ф. 151. Оп. 13. Спр. 583. Арк. 3.

${ }^{44}$ Пекар А. Нариси історії Церкви Закарпаття. Т. ІІІ. Монаше життя... С. 129.
} 
своїх найбільших захисників на Підкарпатській Русі і працювати стало ще важче.

Незважаючи на всі перепони, отці-василіяни все ж зуміли досягнути найголовнішої мети, для якої власне і проводилася реформа - це канонічне створення василіянської провінції святого Миколая. Нагадаємо, що за домовленістю, яка була підписана 4 вересня 1920 р. і затверджена Апостольським Престолом 6 квітня 1921 р. для того, щоб отримати власну провінцію, василіяни Мукачівської єпархії повинні були мати три зреформовані монастирі, 30 ченців 3 довічною професією, з яких хоча б 20 будуть священиками. На момент свого створення Підкарпатська Провінція нараховувала 34 ієромонахів, 51 братівпомічників, 44 схоластики (всього 129 членів) і 19 новиків ${ }^{45}$. Це було навіть більше, ніж достатньо для втілення цілі в життя.

24 вересня 1931 р., протоархімандритом Діонізієм Ткачуком (ЧСВВ) було призначено Гліба Кінаха (ЧСВВ) візитатором монастирів у Чехословаччині, Угорщині, Румунії та Югославії і прозвітував про їх становище. Візитатор успішно виконав свою роботу і на основі цього звіту, Д. Ткачук звернувся до Конгрегації для Східних Церков 3 проханням отримати дозвіл на створення нової Провінції Василіянського Чину ${ }^{46}$.

Успішно пройшовши всі формальності, декретом від 2 квітня 1932 р., було канонічно створено василіянську провінцію на Підкарпатській Русі під назвою - «Провінція Святого Миколая» ${ }^{47}$. До іï складу ввійшли монастирі Угорщини, Румунії та Югославії. 22 липня 1932 р. було призначено першого протоігумена провінції, яким став Петро Булик $^{48}$ та обрано провінційну управу в наступному складі: консультори - Гліб Кінах (ЧСВВ) (представник для монастирів Підкарпатської Русі), Атанасій Максим (ЧСВВ) (представник для монастирів Румунії), Міклош Дудаш (ЧСВВ) (представник для монастирів Угорщини); секретар провінції - Мирон Калинець (ЧСВВ); прокуратор провінції Онуфрій Бурдяк (ЧСВВ) ${ }^{49}$.

За вимушених умов, василіяни проходили навчання на території власної провінції. Після того як у тому ж 1932 р. чехословацька влада заборонила відсилати студентів на студії до Галичини у Малоберезнянському монастирі було відкрито власні студії, де викладали гуманістику та філософію (а з 1934 р. гуманістику було переміщено до Мукачівського монастиря, а філософію та богослов'я - до Ужгородського $)^{50}$. Таким чином, після Галицької провінції «була це друга найсильніша вітка Василіянського чину напередодні Другої світової війни».

У підсумку, реформа, проведена галицькими монахами принесла крім головного здобутку - канонічного створення власної провінції для отців-василіян Підкарпатської Русі - ще й багато інших позитивних зрушень. Першочерговим завданням для новопри-

\footnotetext{
${ }^{45}$ Пекар А. «Василіянська провінція св. Миколая на Закарпатті» // Analecta Ordinis S. Basilii Magni ecclesiae catholicae Ucrainae persecutae dedicate (1945-1990). Sectio II. Vol. XIV (XX). Fasc. 1-4. Romae: Sumptibus PP. Basilianorum, 1992. C. 396.

${ }^{46}$ Ibid. C. 397.

47 Декрет конгрегации г. Рим об образовании провинции ордена им. св. Николая в г. Мукачево для монастырей ордена Василиан в Чехословакии,Венгрии, Румунии и Югославии // ДАЗО. Ф. 64. Оп. 3. Спр. 1549. Арк. 13.

${ }^{48}$ Первый протоигуменъ ЧСВВ посли реформы въ Чер. о. Поликарпъ Буликъ. // Душпастыръ. 1932. Ч. 10. C. 302.

${ }^{49}$ Пекар А. «Василіянська провінція св. Миколая на Закарпатті»... С. 398.

${ }^{50}$ Пекар А. Нариси історії Церкви Закарпаття. Т. ІІІ. Монаше життя... С. 129.
} 
булих ченців було відродження занедбаного чернечого життя та повернення минулої слави василіянським обителям. За досить таки короткий період часу василіянам вдалося відновити та проводити на високому духовному рівні богослужіння, навчання монахів, проведення місій і реколекцій, завдяки яким поширювали часту сповідь і причастя, виховання молоді у християнському дусі.

При спільних реколекціях і місіях відбувалося таке рідкісне єднання вірних різних національностей на релігійному грунті. Одним словом, монахи-василіяни намагалися справно виконувати свої чернечі та духовні повинності, тим самим зміцнюючи позиції ГКЦ на Підкарпатській Русі. Це було дуже важливим у тих умовах, адже греко-католикам потрібні були свіжі сили, щоб протистояти двом опонентам - «схизматикам» і новій назріваючій біді - комунізму.

Завдяки їх плідній і кропіткій праці монастирі із напівруїн перетворилися в осередки релігії, культури та науки, де збиралися тисячі прочан. По всій території Мукачівської єпархії була налагоджена ціла мережа центрів роботи з молоддю, відбувалися постійні зустрічі з вірними з виховними та просвітницькими цілями. Саме тому при монастирях діяли школи-інтернати (пізніше навіть було відкрито класичну гімназію) та всілякі гуртки. Колосальні здобутки спостерігалися й у видавничій справі. У власній друкарні при Ужгородському монастирі випускалася різного роду література - від публіцистики до релігійної літератури та серйозних наукових праць.

Монахи та монахині активно займалися благодійністю, а оскільки для цього потрібно було багато коштів, то вони відродили багатогалузеве господарство при монастирях. Найбільше у напрямку благодійності діяли сестри-василіянки, які опікувалися хворими, бідними та знедоленими, а також на іх утриманні знаходилися місцеві сиротинці, кількість яких за час їх перебування зросла.

Хоча не все було так легко як здається на перший погляд. Монахи-василіяни натикалися на різного роду перешкоди, які ім створювали чехословацька влада, а також місцеві москвофіли, видаючи проти їх діяльності різні статті та пишучи доноси до крайового уряду, різних міністерств і поліції. Головні претензії - це їх «українськість». Інколи навіть доходило до звинувачень в антидержавній діяльності. Завжди на захист ченців ставали владики Петро Гебей, Діонісій Нярядій і Павло Гойдич.

Отже, незважаючи на всі труднощі, які прийшлося пережити монахам-василіянам, їм вдалося досягти неабияких успіхів. Це вони зуміли зробити завдяки своїй наполегливості, безкорисливості та відданості особистій справі. У той період, коли не тільки ЧСВВ знаходився у важкому становищі, а, власне, і Мукачівська єпархія загалом, то саме таких завзятих ентузіастів і потребувала ГКЦ. Адже, незважаючи на всі пересуди, їх основна праця, як поширювачів католицизму, була скерована на досягнення консолідації у грекокатолицькому середовищі. Монахи брали активну участь у громадському та культурнопросвітницькому житті краю. Окремої уваги заслуговує їх видавнича діяльність. Ця реформа заклала основи для заснування окремої гілки ЧСВВ у Мукачівській грекокатолицькій єпархії. 


\title{
Maria Majoroshi
}

\section{Missionary, Cultural and Educational Activities of Galician Basilians in Subcarpathian Rus}

\begin{abstract}
Nowadays, the Order of St. Basil the Great is one of the most authoritative monastic rules of the Ukrainian Greek Catholic Church. However, it should be noted that the OSBM, which is now being influential and respected in society, has come a long historical path up to its establishment. Historical twists and turns that caused the necessity of a radical reformation of the structure, conceptual activities and approaches of the Order's operation. A detailed retrospective analysis of the OSBM's activities will guarantee the contemporaries' awareness of the spiritual principles of the activity of the monks following the Order of St. Basil the Great.

The article, based on published and archival source material, analyzes the directions, content and transformations under the influence of social challenges of missionary and cultural-educational activities of Galician Basilian monks in Subcarpathian Rus. Basilians held an active work with the youth, founded apostolic societies, and were also actively involved in publishing activities. Their missions went far beyond one state. The educational activities of the Basilians gave positive changes in the field of youth education.
\end{abstract}

Keywords: Galician Basilians, Order of St. Basil the Great, reform, church, Transcarpathia 